\title{
Investigating the Relationship between Iranian EFL Teachers' Conformity to Postmethod Principles and Their Academic Success
}

\author{
Khalil Motallebzadeh, Hanieh Garmabi*, Mehri Bakhtiari Fayendari \\ English Department, Torbat-e-Heydarieh Branch, Islamic Azad University, Torbat-e-Heydarieh, Iran \\ Corresponding Author: Hanieh Garmabi, E-mail: Hanieh_Garmabi@yahoo.com
}

\section{ARTICLE INFO}

Article history

Received: August 03, 2017

Accepted: October 04, 2017

Published: January 05, 2018

Volume: 7 Issue: 1

Advance access: December 2017

Conflicts of interest: None

Funding: None

\begin{abstract}
In educational world, the language teaching pendulum is swinging away from methods to postmethod pedagogy although its actual emergence in some contexts is under doubt. The present study aims at pursuing whether Iranian English-as-a-Foreign-Language (EFL) teachers conform their teaching approach to postmethod principles and whether there exists a relationship between teachers' willingness and conformity to post-method pedagogy and their academic success perceived by their students. To this end, an exploratory study was undertaken with a sample size of 102 EFL teachers from a number of private institutes in Iran. The Postmethod |Pedagogy Questionnaire (PPQ) was employed to evaluate the teachers' level of willingness and conformity to the principles of postmethod pedagogy. In addition, the measures of the teachers' professional success were obtained via Characteristics of Successful Iranian EFL Teacher Questionnaire (CSIETQ) which was filled out by the participant-teachers' students. The analysis of one-sample T-test indicated that Iranian EFL teachers do not show significantly high level of willingness and conformity to the principles of postmethod pedagogy. In this regard, educational level does not play any significant influence on the teachers' conformity to postmethod principles, determined by the results of one sample T-test having been run on BA and MA teachers' postmethod conformity. The results of Pearson correlation coefficient demonstrated that there is a significant and positive relationship between conformity to postmethod pedagogy principles and professional success. The results offer implications and suggestions for pedagogical consideration within Iranian EFL context.
\end{abstract}

Key words: Educational Level, Postmethod Pedagogy, Professional Success, Willingness and Conformity to Postmethod Principles

\section{INTRODUCTION}

The last quarter of the twenties century witnessed a number of dramatic changes among which postmodernism is claimed to be the most outstanding. It is a reaction against the naïve acceptance of classroom-management techniques prescribed by outsiders. Professional endeavors to find a relevant and coherent alternative to top-down methods were inspired by boredom with the marginalization of both teachers and learners. Whether educational context has embraced the tenets of such postmodernism ideas in practice is under doubt. There also exists the question whether long-claimed consequences of postmethod pedagogy have been full filed. The present study was undertaken to have an in-depth investigation of these two important concerns.

\section{From Method to Postmethod Era}

For centuries the goal of language teaching had been to find the best method. The practitioners in the field of language teaching had believed that improvement in teaching language results from improvement in the quality of methods. Called absolutism, such an ideology implied that successful teaching is the accurate replication of a method (Prabhu, 1990).

However, over the years, it has been realized that methods marginalize the role of both teachers and learners. Learners' various styles, preferences, and needs are ignored in such a teaching context. Teacher reflection and creativity are also destroyed. In addition, methods are the tools by which European ideologies are imposed to other countries. This cultural imperialism marginalizes the learners' local culture (Larsen-Freeman, 1986, Stern, 1992).

By the end of twenties century, mainstream language teaching no longer regarded the application of methods as the key factor in achieving academic success. Some spoke of the death of methods in terms of post-method pedagogy (Richards \& Rodgers, 2001). Postmethod pedagogy emerged as a response to second language teachers' and researchers' effort in searching for fruitful and realistic ways to best manage teaching profession. This is because the existing teaching methods have been complained not to deliver what they 
promised (Kumaravadivelu, 2003). Freeing teachers from the constraints of the methods, post-method pedagogy has invigorated them by providing a variety of options generated by teachers' own reflection and creativity. Indeed, it is believed to be the most optimal way of language teaching that releases language teachers form the method-based stronghold (Bell, 2003).

\section{Theoretical Frameworks}

The postmethod discourse underpins three principles of language teaching which were proposed by Kumaravadivelu (2001) and addresses the aspects of practice, context, and empowerment respectively. Firstly, it should be the pedagogy of particularity: language teaching is a local phenomenon, influenced by a particular teacher teaching a particular group of learners who pursue a particular set of goals in a particular institutional and particular sociocultural context. Secondly, it is the pedagogy of practicality: instead of being consumers of the theories provided by the others, teachers should autonomously theorize from their practice and practice what they have theorized. Such theories generated by teachers themselves are living and working and involve reflection and action. Thirdly, it should be the pedagogy of possibility: teachers need to pay attention to learners' historical and social identities and develop theories based on not only the educational context but also the broader social, economic, and the political environment in which the learners have grown up.

The death of methods brings about the question that how teachers can have successful teaching in the era when there is no method to follow. Many intellectuals have sought the answer. Kumaravadivelu (1994), for example, recommended a strategic framework for language teaching. It consists of ten macro-strategies which are broad guidelines based on which teachers can generate their own situation-specific techniques. Maximizing learning opportunities, facilitating negotiated interaction, and promoting learner autonomy are some of those macro-strategies, to name a few.

In addition, stern (1992) proposed a strategy framework consisting of three dimensions, namely, the intralingual-crosslingual dimension, the analytic-experiential dimension, and the explicit-implicit dimension. First of all, in the method era, there was an everlasting controversy over the role of native language or the target language in teaching. However, what is important is the use of both depending on the learners' goals, their previous experience in L2, and the context in which the program takes place. The second dimension deals with the choice between explicit formal instruction and message-oriented interaction in a communicative context. Although followers of methods focused merely on one of them, there is no reason to believe that one is the key for a successful language teaching. Thirdly, whether to base teaching on conscious intellectual exercises or indirect and subconscious acquisition was an unanswered question in the method era. The advantages of both, however, should be acknowledged. They should be mixed according to the topic, course objectives and the students' characteristics.

\section{Teacher Role in Postmethod Pedagogy}

The disappearance of methods and the rise of the postmethod debate have stirred a fresh round of the teacher coming to the center of language teaching. Postmethod pedagogy is highly teacher-dependent as it is the teacher who can fulfill the promises of postmethod (Ahmadian \& Erfanrad, 2014). It is promising and insightful in that it respects the role of teachers as constructors of meaning and it accounts for autonomy, agency, and mediated learning (Hosseini, Rashidi, \& Rasti, 2015). Equally convincingly, Kumaravadivelu (2003) argued that it empowers teachers to follow their teaching process based on their teaching experiences as critical thinkers, theorizers, and field practitioners. Teachers explore their own teaching approaches which are socially realistic and contextually sensitive.

Khatib and Fathi (2012) rightly claimed that postmethod pedagogy views the teacher as having autonomy in his/her teaching performance. No longer do they need to be unduly concerned with the congruence of their teaching practice with what outside experts prescribe. They are recommended to rely on their own experiences to manage the teaching process. This very fact requires that teachers be critical and reflectiv practitioners. Tasnimi (2014) stated that competent postmethod teachers are self-directed theorizers constructing their own theory of practice. In doing so, they should affectively analyze their instruction to implement the required changes in order to achieve the desired goals. In a reflective teaching practice, they should refrain from just transmission of a preselected body of knowledge. Khani and Darabi (2014) also identifie the new roles of teachers in postmethod era as evaluators, observers, critical thinkers, theorizers, and practitioners.

\section{Empirical Studies in the ELT Context}

Having been around for at least two decades, many empirical studies have been undertaken to explore the real emergence of postmethod pedagogy in English language teaching. Motlhaka (2015), for an instance, employed a qualitative research approach to explore teachers' professional growth that postmethod pedagogy brings about. The analysis of the data gathered through open-ended questionnaires and in-depth interviews indicates that teachers report a sense of ownership of their teaching practice. Teachers extend their research skills, reflect on the teaching process, and adopt a critical outlook toward their professional action. Postmethod pedagogy also necessitates that teachers be empowered so that they can be great sources to create meaningful learning environment while striving their professional growth.

Saengboon (2013) solicited university professors' opinions concerning postmethod pedagogy through qualitative case study. Having a sufficient level of understanding of postmethod pedagogy, the participants viewed it as a break away from traditional methods of instruction and from a banking pedagogy to an empowering pedagogy. To apply the principles of postmethod pedagogy in classrooms, they emphasized going beyond linguistic input, incorporating a humanistic stance toward English teaching, and incorporating form, function, and meaning. 
Khani and Darabi (2014) explored the reflection of principle-based and postmethod pedagogy in teachers' performance in Iranian ELT context, exploiting a checklist which evaluates teachers' performance across the principles. The results determined that principle-based and postmethod pedagogy are not highly applied in Iranian classrooms. Some variables, like teaching experience, educational level, and gender are identified to affect teachers' performances regarding the application of principles-based and post-method features. As educational degree increases, the teachers' performance becomes more principles-based. Teachers' performance is also influenced by their gender. The teaching of male teachers is more based on principles-based and post-method pedagogy than females. Similar results were also gained by Razmjoo, Ranjbar, and Hoomanfard (2013) who demonstrated that Iran's teaching practice is manly based on eclectic teaching. The feasibility and practicality of a fully post-method based teaching pedagogy in Iranian context is under doubt. In the same vein, Mardani and Moradian (2016), in a mix-method research, proved that while well aware of the principles of postmethod era, Iranian EFL teachers face many limitations in implementing the teaching practice based on its criteria.

Fathi, Ghaslani, and Parsa (2015) explored the amount of go-togetherness between the extent to which Iranian English teachers show conformity and willingness to the principles of postmethod pedagogy and the degree of their reflection in classrooms. The result of Pearson correlation analysis indicated a significantly positive relationship between the variables, substantiating the compatibility and congruence of willingness to postmethod and reflective thinking. Similarly, Dagkiran (2015) investigated the relationship between EFL teachers' perception of postmethod pedagogy and reflective practices. The analysis of the data revealed that the principles of postmethod pedagogy and the elements of reflective practices interrelate especially with regard to local needs, critical reflections on teaching, and socio-political issues

\section{PURPOSE OF THE STUDY}

In the era when following methods is believed to make teachers slave to imperialistic ideas, equipping teachers with necessary skills to autonomously manage their teaching practice has long been the main focus of post-method practitioners. In this line, exploring whether teachers are really willing to and conform to the principles of post-method pedagogy is indeed vital. In addition, whether such conformity can lead to higher academic success is illuminating as far as teacher education programs are concerned. Although a few numbers of studies (e.g. Fathi et al., 2015; Khany \& Darabi, 2014; Mardani \& Moradian, 2016) addressed the application of post-method pedagogy in Iranian context, clearly, a need exists for sharper focus on this subject. This line of research is of great importance because whether an innovation in language teaching is successfully implemented depends on teachers' opinions about it. Postmethod pedagogy stands out as an example of the conceptualization of an innovative idea, thereby deserving to be studied seriously.

Hence, this study is an attempt to pursue whether Iranian EFL teachers conform their teaching approach to postmethod principles. In this line, the influence of teachers' educational level on their willingness to postmethod pedagogy is also explored. Finally, the study aims at finding whether there exists a relationship between teachers' willingness and conformity to post-method pedagogy and their academic success perceived by their students. The research presented here aims at finding out answers to the following questions

- Do Iranian EFL teachers show significantly high level of willingness and conformity to the principles of postmethod pedagogy?

- Is there any significant difference between Iranian EFL teachers holding BA and those holding MA in terms of the level of willingness and conformity to postmethod principles?

- Is there a significant relationship between the extent to which Iranian EFL teachers show willingness and conformity to the principles of postmethod pedagogy and their professional success?

Null hypotheses were formed to examine the research questions.

\section{METHODOLOGY}

\section{Participants}

To answer the research question, 102 Iranian teachers (43 males, 59 females) teaching EFL at pre-intermediate, intermediate, and advanced levels in private institutes took part in the study. The participants range in age from 19 to 34 and in teaching experience from 8 months to 14 years. They were selected based on the convenience sampling method from Khorasan Province in the cities Neishabour, Mashdad, Sabzevar, and Birjand. In Iranian context, the graduates of different branches of English language field (English Teaching, English Translation, and Linguistics) can enter the teaching profession. For the participants to be fully aware of the principles of language teaching so that the aim of the study can be validly achieved, the teachers who hold BA or MA degrees (57 and 45 respectively) just in English Teaching were chosen.

As the teachers' academic success is identified based on their students' perceptions, there is also a second group of participants. They are 1744 male and female learners, the students of the teacher-participants at that time. They range in age from 16 to 45 and studied English language in the above-mentioned institutes. The number of students who provided the measures of professional success for each teacher ranged from 12 to 22 . For both groups, no distinction is made between the males and females.

\section{Instrumentation}

In order to address the research questions, the following instruments were used.

\section{Postmethod pedagogy questionnaire (PPQ)}

In order to measure teachers' conformity and willingness to post-method principles, the Postmethod Pedagogy 
Questionnaire, designed and validated by Fathi et al. (2015) was employed. It is a 29-item questionnaire developed on the basis of three factors of teacher sense of social justice, teacher autonomy, and teacher sense of academic enthusiasm. Each item is followed by a 6-point likert scale, ranging from 'strongly agree' to 'strongly disagree'. The reliability of the questionnaire, computed by Crobach alpha, was reported to be 0.78 . This approves its reliability.

\section{Characteristics of successful iranian EFL teacher questionnaire (CSIETQ)}

To obtain the measures of teacher success through student evaluation, a 47-item questionnaire on the characteristics of successful Iranian EFL teachers, developed and validated by Moafian and Pishghadam (2008), was utilized. They reported that the questionnaire measures 12 constructs: teaching accountability, interpersonal relationships, attention to all, examination, commitment, learning boosters, creating a sense of competence, teaching boosters, physical and emotional acceptance, empathy, class attendance, and dynamism. The learners responded on a 5-point Likert scale, ranging from 'strongly agree' to 'strongly disagree'. The reliability of the questionnaire was computed by Crobach alpha and was reported to be 0.81 . It shows that the results of the questionnaire are satisfactorily reliable in terms of their internal consistency.

\section{Procedure}

To obtain the measures of the teachers' willingness and conformity to postmethod principles, the teachers were asked to take PPQ. Each teacher was shortly introduced to the purpose of the research and was provided with some brief oral instruction on how to complete them. They took the questionnaire home, filled it in, and submitted it to the researcher in a week. In addition, their students were asked to fill out CSIETQ in their regular class time to evaluate the teachers' professional success. To receive a reliable evaluation by the learners, the researchers explained the purpose of completing the questionnaire and assured them that their views would be confidential Effort was made to observe the confidentiality and anonymity considerations. Having collected the data, the researcher set off on data analysis to answer the research questions using SPSS, version 16. First of all, one-sample T-test was run to identify whether the teachers show significantly high levels of conformity to postmethod pedagogy. Next, independent sample T-test was used to explore whether teachers holding BA and those holding MA differed significantly regarding their willingness and conformity to postmethod principles. Finally, Pearson correlation coefficient was employed to fin out any possible go-togetherness between teachers' willingness to postmethod principles and their professional success.

\section{RESULTS}

\section{Conformity to the Principles of Postmethod Pedagogy}

To test the first null hypothesis, Iranian EFL teachers do not show significantly high level of willingness and conformity to the principles of postmethod pedagogy, one-sample T-test was run on the mean score of the conformity to postmethod pedagogy.

Table 1 reports the results of one-sample T-test run on the mean score of the conformity to postmethod principles. As regards the Postmethod Pedagogy Questionnaire, the maximum score that can be obtained and implies the highest degree of conformity to the tenets of a postmethod-based pedagogy equals 139 . The minimum score indicating the lowest degree of conformity to postmethod principles is 64 and the middle score is nearly 101 . To statistically analyze the mean score, the number 101 was considered to be the criterion value. As it can be clearly seen, there is a significantly low level of willingness and conformity to the principles of postmethod among the teachers $(\mathrm{t}=-2.6, \mathrm{p}<0.05)$. This fin ing confirms the first hypothesi

\section{The Influence of the Educational Level on Conformity to Postmethod Principles}

In order to find the influence of educational level on willingness and conformity to postmethod pedagogy, independent-sample T-test was applied.

The results of independent-sample T-test run on the on the mean scores of postmethod conformity of the teachers holding BA and those holding MA are depicted in the Table 2. The P-value $(\operatorname{sig}>0.05, \mathrm{t}=0.23)$ indicates that the teachers holding BA and those holding MA did not differ significantly in terms of their willingness and conformity to apply the principles of postmethod pedagogy in their teaching approach. This confirms the second hypothesis that there is no significant difference between Iranian EFL teachers holding BA and those holding MA in terms of the level of willingness and conformity to postmethod principles.

\section{The Relationship between Conformity to Postmethod Pedagogy and Professional Success}

From a statistical perspective, the assumption behind the third null hypothesis was that there is no significant relationship between the extent to which Iranian EFL teachers show willingness and conformity to the principles of postmethod pedagogy and their professional success. To test this hypothesis, Pearson correlation coefficient was conducted on the conformity to postmethod pedagogy and professional success scores.

Table 3 presents the result of Pearson correlation run to identify whether there is a significant relationship between conformity to the principles of postmethod pedagogy and professional success scores. It can be clearly seen that there is a statistically significant and fairly strong and positive relationship $(\mathrm{P}<0.05, \mathrm{r}=0.79)$ between the variables. This indicates that the more the teachers conform their teaching approach to the principles of postmethod pedagogy, the more they enjoy professional success, perceived by their students, and vice versa. Such a result rejects the third hypothesis that there is no significant relationship between the extent to which Iranian EFL teachers show willingness and conformity to the principles of postmethod pedagogy and their professional success. 
Table 1. One-sample T-test results for the mean score of the conformity to postmethod pedagogy principles

\begin{tabular}{cccccccc}
\hline & N & Mean & Standard deviation & Standard error mean & t & Df & Sig \\
\hline Postmethod conformity & 102 & 95.83 & 19.57 & 1.93 & -2.66 & 101 & 0.009 \\
\hline
\end{tabular}

Table 2. Independent-sample T-test results for the mean scores of the conformity to postmethod pedagogy of the Teachers holding BA and MA

\begin{tabular}{|c|c|c|c|c|c|c|c|}
\hline & $\mathbf{N}$ & Mean & Standard deviation & Standard error mean & $\mathbf{t}$ & df & Sig \\
\hline BA teachers & 57 & 96.25 & 19.52 & 2.58 & 0.23 & 100 & 0.81 \\
\hline MA teachers & 45 & 95.31 & 19.86 & 2.96 & & & \\
\hline
\end{tabular}

Table 3. The results of pearson correlation coefficient between conformity to postmethod principles and professional success scores

\begin{tabular}{lcc}
\hline & $\begin{array}{c}\text { Postmethod } \\
\text { conformity }\end{array}$ & $\begin{array}{c}\text { Professional } \\
\text { success }\end{array}$ \\
\hline Postmethod conformity & 1 & $0.79^{* *}$ \\
Pearson correlation & 102 & 0.00 \\
Sig (2-tailed) & & 102 \\
N & $0.79^{* *}$ & \\
Professional success & 0.00 & 1 \\
Pearson correlation & 102 & 102 \\
Sig (2-tailed) & \\
N &
\end{tabular}

***Correlation is significant at the 0.01 level

\section{DISCUSSION}

After the experienced dissatisfaction with the language teaching methods and approaches in the early and mid- twentieth century, the notion of postmethod pedagogy was deemed a viable solution to the problems that methods created for both language teachers and learners (Brown, 2000). Given the dearth of research on teachers' willingness to postmethod pedagogy, the purpose of this study was to ascertain whether Iranian EFL teachers show conformity and willingness to postmethod pedagogy and whether this conformity correlate with their professional success.

In terms of the first hypothesis of the study, it was found that EFL teachers did not show a significantly high level of willingness and conformity to the principles of postmethod pedagogy. This has consistency with the results gained by Khani and Darabi (2014), Razmjoo, et al. (2013), and Mardani and Moradian (2016), who confirmed that postmethod pedagogy is not highly applied in EFL Iranian classes. Pishghadam, Askarzade, and Navari (2009) and Pourali (2011) also asserted that Iran's educational system, in both schools and universities, is still under the influence of Behaviorist views of learning.

EFL teachers' unwillingness to the principles of postmethod pedagogy can stem from various factors. Firstly, Iranian educational system is still living in the method era (Pishghadam \& Mirzaee, 2008). Unfortunately, such methods like Audio-lingual and Grammar-translation with their strong adherence to form rather than function, teacher authority rather than learner-centeredness, memorization rather than genuine interaction, and deductive rather than inductive approach to teaching are dominant. Spending seven years at junior and senior high-school and pre-university levels, few learners leave the system with a high command of English. The situation is not much better when learners take up TEFL as their major at university at both BA and MA levels. Pishghadam and Shirmohammadi (2012) argued that the repetition and memorization are the dominant teaching practices in the TEFL field at the MA level. Ghapanchi and Talebi (2012) also stated that critical reflective actions have no place in the field of TEFL at both BA and MA levels. That is the reason why the second hypothesis of the study was also confirmed and no significant difference between teachers holding $\mathrm{BA}$ and those holding MA regarding their conformity to the principles of postmethod pedagogy was found. Naturally, when the prospective teachers leave the system, the resume the same teaching approach they have been taught through.

Secondly, EFL private institutes in Iran are considered to be business sources bringing about great financial interest only for the administrators. Classes usually include a large number of students yet the minimum number of facilities. Handling such classes necessitates great energy invested on the part of teachers who are highly poorly paid. In some institutes, hardly, is ten percent of the whole income of one class is paid to the teacher. Thus, the teachers do not push themselves to spend too much time and energy to equip themselves with the latest movements in language teaching. This is because, unfortunately, the pay they earn is not equal to the endeavors they make at all.

Kennedy and Kennedy (1996) asserted that an intention to change a particular behavior originates from not only one's attitude but also the subjective norms and the behavioral controls. This implies that, to fully apply the tenets of postmethod pedagogy in Iranian context, not only teachers' attitudes but also administrative norms have to be changed. It seems that Iranian educational system, from high-schools to universities, must undergo radical changes. According to Kumaravadivelu (2003), reshaping the character and the content of second language teaching, teacher education, and classroom activities, postmethod pedagogy is the optimal way of teaching English. It is rightly the time when EFL teaching in Iran moves away from being enslaved to the 
ideologies of methods to a liberating pedagogy empowering both teachers and learners.

The rejection of the third hypothesis of the study implies that teachers' conformity to postmethod principles correlate with their professional success. This is hardly surprising as there is relative proximity between the underlying elements of the two variables in terms of their nature and domain. For example, the construct teacher accountability in the CSIETQ was defined by Moafia and Pishghadam (2008) as being interested in the subject being taught, being interested in helping students, and accepting criticism. The nature of this construct corresponds to teacher sense of academic enthusiasm in PPQ. Another construct is attention to all in CSIETQ which is characterized as creating equal opportunities for all learners in the process of learning and avoiding discrimination against students. Obviously this element is similar to teacher sense of social justice in PPQ. Finally, the domain of the construct dynamism in CSIETQ is in line with that of teacher autonomy in PPQ as both of them incorporate creativity and variety in teaching.

The findings of this study can generally contribute to the body of postmethod pedagogy literature. More specificall , findings of this study may offer insights for those involved in educational administrations, syllabus design, curriculum planning, and materials development. The fact that although conformity to postmethod principles can bring about great success in educational realm, those principles are not highly applied in Iranian educational context is a caution for them. They are required to launch teacher training sessions, performance evaluation, and regular performance feedback to equip teachers with the latest movements in EFL. The advocate of postmethod pedagogy seems right in associating Iranian EFL teaching with learners' lack of sufficient proficienc. Teachers also can benefit from the findings of this study. Undoubtedly, the tenets of postmethod pedagogy highly emphasize the teacher as a reflective decision-maker agent who is a critical examiner of classroom practices to come up with different ideas to enhance learners' achievement. This has a therapeutic effect to get rid of all the obstacles that the method era created for the enslaved teachers.

While the present study was extensive in the range of statistical and logical analysis undertaken, it is important to acknowledge the limitation regarding the sample of the participants. To put in more specific words, the selection and the number of the institutes in general and the teachers in particular were subject to permission and administrative selection. Generally, test and inventory replying is always dependent on the participants' availability and good will. In other words, the choice of the participants can be considered as a kind of purposive sampling rather than a random one. Indeed, to meet the ethical requirements, such an issue is inevitable. Moreover, there is the problem of having the students as the only source for providing information regarding teachers' professional success. Learners' evaluation can be influenced by class content, teacher characteristic, and timing of the evaluation. The researchers believe that the evaluations could have been more reliable if it were possible to triangulate the data through other sources like information on learners' longitudinal success.

The researchers suggest some hints to be taken into consideration for replication of this study. Further research can be conducted in other institutes and on a larger sample, helping a solid understanding of the relationship between the variables. In addition, studies can be conducted in high schools to compare the results. Moreover, the studies in which teachers' age and gender are taken into account can yield more generalizable results. Finally, subsequent studies can make use of other kinds of data collection procedures like observation.

\section{REFERENCES}

Ahmadian, M., \& Erfanrad, S. (2014). Postmethod era and glocalized language curriculum development: A fresh burden on language teachers. Journal of Language Teaching and Research, 5(3), 592-594. 10.4304/ jltr.5.3.592-598.

Bell, D. M. (2003). Method and post method: Are they really so incompatible? TESOL Quarterly, 37(2), 325-336.

Brown, H. D. (2000). Principles of language learning and teaching. New York: Pearson Education.

Dagkiran, I. (2015). Postmethod pedagogy and reflective practice: Current stance of Turkish EFL. Unpublished MA thesis, Ihsan Dogramaci Bilkent University.

Fathi, J., Ghaslani, R., \& Parsa, K. (2015). The relationship between post-method pedagogy and teacher reflection: A case of Iranian EFL teachers. Journal of Applied Linguistics and Language Research, 2(4). 305-321.

Ghapanchi, Z., \& Talebi, F. (2012). A comparison between roles of professors teaching English Literature or TEF1 at BA level and professors teaching TEFL at MA level in the light of Goffman's footing theory. World Journal of Education, 2, 33-44.

Hosseini, S. A., Rashidi, N., \& Rasti, A. R. (2015). Postmethod pedagogy: Ally or foe. International Journal of English Language, Literature, and Translation Studies, 2(3), 322-331.

Kennedy, C., \& Kennedy, J. (1996). Teacher attitudes and change implementation. Pergamon, 24(3), 351-360.

Khany, R., \& Darabi, R. (2014). ELT in Iran: Reflection of the principle-based and post-method pedagogy in language teaching. Procedia Social and Behavioral Sciences, 98, 908-916. 10.1016/j.sbspro.2014.03.499.

Khatib, M., \& Fathi, J. (2012). Postmethod pedagogy and ELT teachers. Journal of Academic and Applied Studies, 2(2), 22-29.

Kumaravadivelu, B. (1994). The post method condition: (E) merging strategies for second/foreign language teaching. TESOL Quarterly, 28, 27-48.

Kumaravadivelu, B. (2001). Toward a post method pedagogy. TESOL Quarterly, 35(4), 537-560.

Kumaravadivelu, B. (2003). Critical language pedagogy: A postmethod perspective on English language teaching. World Englishes, 22(4), 539-550.

Larsen-Freeman, D. (1986). Techniques and principles in language teaching. Oxford: Oxford University Press. 
Mardani, M., \& Moradian, E. (2016). Postmethod pedagogy perception and usage by EFL teachers and learners and its limitations, symbols, and viewpoints. International Journal of Language Learning and Applied Linguistics World, 11, 75-88.

Moafian, F., \& Pishghadam, R. (2008). Tahie vabaresie etebare sazeye porseshnameye vizhegihaye modaresane movafaghe zabaneenglisi. Pazhooheshe Zabanhaye Khareji, 54, 127-141.

Motlhaka, H. A. (2015). Exploring postmethod pedagogy in teaching English as a second language in South African higher education. Mediterranean Journal of Social Studies, 6, 517-524. 10.5901/mjss.2015.v6n1p517

Pishghadam, R., Askarzadeh, R. A., \& Navari, S. (2009). Metaphor analysis of teachers' beliefs and conceptions of language teaching and learning in Iranian high schools and language institutes: A qualitative study. Iranian EFL Journal, 4, 6-40.

Pishghadam, R., \& Mirzaee, A. (2008). English language teaching in postmodern era. Journal of Teaching English Language and Literature, 2(7), 89-109.

Pishghadam, R., \& Shirmohammadi, S. (2012). Professional identity in Iran's higher education: A case of EFL professors. Journal of Educational and Social Research, 2, 317-328. 10.5901/jesr.2012.02.01.317.
Pourali, S. (2011). Metaphor analysis of beliefs about teaching and learning in the current and ideal situations: A case of professors and students majoring in English language teaching and literature. Unpublished MA thesis, Ferdowsi University of Mashhad.

Prabhu, N. S. (1990). There is no best method-Why? TESOL Quarterly, 24(2), 161-176.

Razmjoo, S. A., Ranjbar, H., \& Hoomanfard, M. H. (2013). On the familiarity of Iranian teachers and learners with postmethod and its realization. International Journal of Language Learning and Applied Linguistics World, 4, 1-12.

Richards, J. C., \& Rodgers, T. S. (2001). Approaches and methods in language teaching. Cambridge: Cambridge University Press.

Saengboon, S. (2013). Thai English teachers' understanding of "postmethod pedagogy": A case of studies of university lecturers. English Language Teaching, 6(12), 156166. 10.5539/elt.v6n12p156.

Stern, H. H. (1992). Issues and options in language teaching. Oxford: Oxford University Press.

Tasnimi, M. (2014). The role of teacher in the post method era. International Journal of Multi Disciplinary Research, 1(3), 1-8. 